\title{
The cationic tetradecapeptide mastoparan as a privileged structure for drug discovery: Enhanced antimicrobial properties of mitoparan analogues modified at position-14
}

\author{
John Howl*, Lewis Howl, Sarah Jones \\ Research Institute in Healthcare Science, Faculty of Science and Engineering, University of Wolverhampton, Wulfruna Street, Wolverhampton, WV1 1LY, United Kingdom
}

\section{A R T I C LE INFO}

\section{Keywords:}

Mastoparan

Mitoparan

Antimicrobial

Antifungal

Cell penetrating peptide

\begin{abstract}
A B S T R A C T
Mastoparan (MP) peptides, distributed in insect venoms, induce a local inflammatory response post envenomation. Most endogenous MPs share common structural elements within a tetradecapeptide sequence that adopts an amphipathic helix whilst traversing biological membranes and when bound to an intracellular protein target. Rational modifications to increase cationic charge density and amphipathic helicity engineered mitoparan (MitP), a mitochondriotoxic bioportide and potent secretagogue. Following intracellular translocation, MitP is accreted by mitochondria thus indicating additional utility as an antimicrobial agent. Hence, the objectives of this study were to compare the antimicrobial activities of a structurally diverse set of cationic cell penetrating peptides, including both MP and MitP sequences, and to chemically engineer analogues of MitP for potential therapeutic applications. Herein, we confirm that, like MP, MitP is a privileged structure for the development of antimicrobial peptides active against both prokaryotic and eukaryotic pathogens. Collectively, MitP and target-selective chimeric analogues are broad spectrum antibiotics, with the Gram-negative A. baumannii demonstrating particular susceptibility. Modifications of MitP by amino acid substitution at position-14 produced peptides, $\Delta 14 \mathrm{MitP}$ analogues, with unique pharmacodynamic properties. One example, $\left[\operatorname{Ser}^{14}\right]$ MitP, lacks both cytotoxicity against human cell lines and mast cell secretory activity yet retains selective activity against the encapsulated yeast $C$. neoformans.
\end{abstract}

\section{Introduction}

Animal venoms usually comprise a complex mixture of peptide toxins that act potently and rapidly when envenomated into soft tissues [1]. Such venoms are, therefore, a remarkable resource for the discovery of bioactive peptides highly active against every generic class of protein drug target. Approximately $50 \%$ of the venom of the Korean leather-jacket Vespula lewisii consists of the peptide mastoparan (MP; INLKALAALAKKIL), named to signify its capacity to activate mast cell secretion by a receptor-independent mechanism [2]. Moreover, as described herein, MP is not a peptide species but rather a genus of structurally related tetradecapeptides from hymenopteran venoms which induce receptor-independent mast cell degranulation to promote pain and other local inflammatory responses [3].

The term privileged scaffold was introduced by Evans et al. [4] to serve as a general descriptor of a molecular framework or architecture that can be readily modified to produce ligands for distinct receptors.
This original study focussed upon the advantages of the benzodiazepine nucleus that seemingly resulted from the molecular mimicry of a beta turn. However, since this time a variety of other privileged structures and scaffolds have been identified and exploited [5] of which examples pertinent to this study include peptides, peptoids, cyclic peptides and a variety of conformation-constrained structural mimetics [6,7]. There are several structural motifs almost invariably maintained by all endogenous MPs. Ile always occupies the amino terminus of endogenous peptides. Enzymatic cleavage of Ile $^{1}$ by enzymes in human serum is relatively slow, but the resulting tridecapeptide, NLKALAALAKKIL, has much reduced activity against Gram-negative Acinetobacter baumannii compared with MP [8]. The MP tetradecapeptides are cationic in nature, positive charges being contributed mostly by the $\varepsilon$-amino function of multiple Lys residues. Leucinamide usually occupies the carboxyl-terminal of endogenous MP analogues and loss of the amide function is detrimental to biological activities including erythrocyte lysis and mast cell degranulation $[9,10]$. The formation of an amphipathic alpha helix is also a major determinant of the many activities of MP peptides. The

Abbreviations: Aib, 2-aminoisobutyric acid; MitP, mitoparan; MP, mastoparan.

* Corresponding author.

Email address: J.Howl@wlv.ac.uk (J. Howl) 
structure of MP is disordered in aqueous solution but becomes helical in the presence of lipids and membrane mimetics $[11,12]$. MP is also helical when bound to a primary intracellular protein target, namely pertussis toxin-sensitive heterotrimeric $G$ proteins $[13,14]$. As reviewed elsewhere $[15,16]$, the privileged nature of MP peptides enables them to influence the activities of many additional protein targets that include $\mathrm{Ca}^{2+}$-ATPases [17], calmodulin [18] and glycogen phosphorylase [19].

The capacity of MP peptides to translocate cell membranes as an amphipathic helix facilitates the presentation of a cationic hydrophilic face on the inner side of the plasma membrane. This in turn mimics some structural determinants of activated $\mathrm{G}$ protein-coupled receptors [3,20-22]. Hence, the design of mitoparan (MitP; [Lys $\left.{ }^{5,8}, \mathrm{Aib}^{10}\right] \mathrm{MP}$; $\mathrm{Aib}=2$-aminoisobutyric acid) was dictated by the strategy of substituting additional cationic charge into the hydrophilic face of MP [23]. The substitution of $\mathrm{Ala}^{10}$ with Aib, a known helix promoter [24,25], was intended to both increase the propensity for helix formation and also confer resistance to proteases. The design of MitP deliberately included Ile $^{1}$ and leucinamide ${ }^{14}$ to maintain some structural determinants of the privileged scaffold of MP. When directly compared with MP [23], MitP is a more potent secretagogue of $\beta$-hexosaminidase, a secretory granule marker, from RBL-2H3 mast cells and displays enhanced cytotoxicity when exogenously added to U373MG astrocytoma cells. Of specific relevance to this study, MitP and chimeric analogues, N-terminally extended with additional homing motifs, are specifically accreted by mitochondria following their efficient cellular translocation into eukaryotic cells $[26,27]$. Moreover, MitP promotes apoptosis through mechanisms that include the increased phosphorylation of mitogen-activated protein kinases and the release of cytochrome $c$ from mitochondria $[23,26]$. The latter response is mediated, at least in part, by the modulation of voltage-dependent ion channels (VDAC) expressed in mitochondrial membranes [26].

As further described herein, endogenous MP analogues are reported to display a wide range of antibiotic activities. Thus, we reasoned that MitP, a peptide that specifically accretes within mitochondria, could be further engineered as an antibacterial agent. Accepting the endosymbiotic origin of the eukaryotic mitochondrion [28], we considered it likely that MitP analogues could also interact with both the lipid and protein constituents of prokaryotic cell membranes. However, it is obvious that the clinical utility of any antibiotic peptide that simultaneously promotes mast cell degranulation and/or eukaryotic cell death would be severely compromised. Thus, the major objective of this study was to identify MitP analogues with more desirable and selective antibiotic properties. When modelled as a classic $\alpha$-helix, the highly conserved aliphatic side chain of leucinamide ${ }^{14}$ clearly contributes to the hydrophobic face of endogenous MP sequences. Our approach to this problem was to subtly perturb the privileged structure of MitP through the selective modification of the carboxyl terminal. Our findings provide powerful evidence that minor changes to the privileged structure of MitP can indeed be employed to engineer selective antibacterial and antifungal agents.

\section{Materials and methods}

\subsection{Materials}

Fluorenylmethyloxycarbonyl (Fmoc)-protected amino acids for microwave-assisted peptide synthesis were purchased from Novabiochem (Beeston, UK). AGTC Bioproducts Ltd (Hessle, UK) supplied dimethylformamide, dichloromethane and piperidine for solid phase peptide synthesis. Mammalian culture medium and supplements were purchased from Sigma-Aldrich (Poole, UK). Microbial assay plates were purchased from Corning (Australia). Bacterial growth medium was purchased from Bacto Laboratories (Mount Ptitchard, NSW, Australia) and fungal growth medium and culture agar from Becton Dickinson (North Ryde, NSW, Australia). Unless otherwise indicated all other research grade chemicals were purchased from Sigma-Aldrich (Poole, UK or Castle Hill, NSW, Australia).

\subsection{Microwave-assisted solid phase peptide synthesis}

Solid phase peptide syntheses were performed using a Discover SPS Microwave Peptide Synthsizer (CEM Microwave Technology Ltd, Buckingham, UK) with fibre optic temperature control [29]. Peptides were synthesized ( $0.1 \mathrm{mmol}$ scale) using Rink amide MBHA resins pre-loaded with the first amino acid (AnaSpec, Inc. Cambridge Bioscience Ltd, Cambridge, UK) and employed an $\mathrm{N}-\alpha$-Fmoc protection strategy with $O$-(1H-6-Chlorobenzotriazole-1-yl)-1,1,3,3-tetramethyluronium hexafluorophosphate (HCTU; AGTC Bioporoducts) activation. Deprotection with $7 \mathrm{ml}$ of $20 \%$ piperidine was performed for $3 \mathrm{~min}$ at $50 \mathrm{~W} / 75^{\circ} \mathrm{C}$. A majority of AA coupling reactions were accomplished with a 4-fold molar excess of Fmoc-protected AA with HCTU and diisopropylethylamine (DIPEA), molar ratio of 1:1:2 (AA/HCTU/DIPEA), in $4 \mathrm{ml}$ for $10 \mathrm{~min}$ at $25 \mathrm{~W} / 75^{\circ} \mathrm{C}$. Arg coupling was performed in two stages: $30 \mathrm{~min}$ $0 \mathrm{~W} / \sim 25^{\circ} \mathrm{C}$ followed by $5 \mathrm{~min}$ at $17 \mathrm{~W} / 75^{\circ} \mathrm{C}$. To reduce racemization of Cys and His, coupling conditions were $5 \mathrm{~min}$ at $0 \mathrm{~W} / \sim 25^{\circ} \mathrm{C}$ followed by $6 \mathrm{~min}$ at $17 \mathrm{~W} / 50^{\circ} \mathrm{C}$ with the hindered base collidine (TMP) at molar ratio of 1:1:2 (AA/HCTU/TMP) [30]. Aspartimide formation was reduced by the substitution of piperidine with $5 \%$ piperazine and $0.1 \mathrm{M} 1$-hydroxybenztriazole hydrate (HOBt) in the deprotection solution [30].

Fluorescent peptides to be used in confocal live cell imaging were synthesised by amino-terminal acylation with the single isomer 6-carboxy-tetramethylrhodamine (TAMRA; Novabiochem, Beeston, UK).

All peptides were purified to apparent homogeneity by semi-preparative scale high performance liquid chromatography and lyophilised. As reported herein (Table 2), the predicted masses of novel MitP analogues described in this study (average $\mathrm{M}+\mathrm{H}^{+}$) were confirmed by matrix-assisted laser desorption ionization (MALDI) time of flight mass spectrometry operated in positive ion mode [26].

\subsection{Mammalian cell culture}

Rat basophilic leukaemia cells (RBL-2H3) are widely employed as an accepted mucosal mast cell model for the investigation of regulated secretory phenomenon and were therefore used to evaluate the secretory effects of MitP analogues [29,31,32]. RBL-2H3 were maintained in Dulbecco's Modified Eagle's Medium (DMEM) containing L-glutamine $(0.1 \mathrm{mg} / \mathrm{ml})$ supplemented with foetal bovine serum $10 \%(\mathrm{v} / \mathrm{v})$, penicillin $(100 \mathrm{U} / \mathrm{ml})$ and streptomycin $(100 \mu \mathrm{g} / \mathrm{ml})$ in a humidified atmosphere of $5 \% \mathrm{CO}_{2}$ at $37^{\circ} \mathrm{C}$.

U373MG human astrocytoma cells are an extensively-characterised and routinely-used cellular model within our laboratory for the investigation of peptide-induced cytotoxic events [26,31,33] and were therefore used to determine the cytotoxicity profiles of MitP analogues. HEK293 cells were additionally utilised for cytotoxic screening. Both U373MG and HEK293 were maintained in DMEM as above.

\subsection{Secretory efficacies of MP and MitP analogues}

To determine the secretory efficacies of polybasic peptides, the exocytosis of $\beta$-hexosaminidase, a secretory lysosomal marker, was determined in RBL-2H3 cells as previously described [29,34-36]. B-Hexosaminidase was assayed in samples of cell medium following exogenous application of peptides to RBL-2H3 cells in HAMS F12 medium. $5 \mu$ Aliquots of medium were transferred into 96 well plates and incubated with $\rho$-nitrophenyl- $N$-acetyl-ß-D-glucosamide $(20 \mu \mathrm{l}$ of $1 \mathrm{mM}$ in 
$0.1 \mathrm{M}$ sodium citrate buffer, $\mathrm{pH} 4.5$ ) for $1 \mathrm{~h}$ at $37^{\circ} \mathrm{C} . \mathrm{Na}_{2} \mathrm{CO}_{3} / \mathrm{NaHCO}_{3}$ buffer $(200 \mu \mathrm{l}$ of $0.1 \mathrm{M}, \mathrm{pH} 10.5)$ was then added and B-hexosaminidase activity determined by colourimetric analysis at $405 \mathrm{~nm}$.

\subsection{Eukaryotic cytotoxicity assays}

Peptide-induced changes in cellular viability were quantitatively assessed using the 3-(4,5-dimethylthiazol-2-yl)-2,5-diphenyl tetrazolium bromide (MTT) conversion assay [26,37]. U373MG cells were cultured as above in 96 well plates, treated with peptides for $4 \mathrm{~h}$ at $37^{\circ} \mathrm{C}$, and further incubated with MTT $(0.5 \mathrm{~g} / \mathrm{L})$ for $3 \mathrm{~h}$ at $37^{\circ} \mathrm{C}$. The insoluble formazan product was solubilised with DMSO and MTT conversion determined by colorimetric analysis at $540 \mathrm{~nm}$. Cellular viability was expressed as a percentage of those cells treated with vehicle (medium) alone. Graphical representations of changes in cell viability were calculated using GraphPad Prism 7 software.

Peptide-induced changes in eukaryotic cell viability were also performed by the CO-ADD (Community for Antimicrobial Drug Discovery) and used HEK293 cells. Cells were counted manually in a Neubauer haemocytometer and then plated in 384-well plates containing peptides to give a density of 6000 cells/well in a final volume of $50 \mu \mathrm{L}$ and incubated for $20 \mathrm{~h}$ at $37^{\circ} \mathrm{C}$ in $5 \% \mathrm{CO}_{2}$. Cytotoxicity was measured by fluorescence, Ex: 560/10 nm, Em: 590/10 nm ( $\left.\mathrm{F}_{560 / 590}\right)$, after addition of $5 \mu \mathrm{L}$ of $25 \mathrm{mg} / \mathrm{L}$ Resazurin $(2.3 \mathrm{mg} / \mathrm{L}$ final concentration) and after incubation for a further $3 \mathrm{~h}$ at $37^{\circ} \mathrm{C}$ in $5 \% \mathrm{CO}_{2}$. The fluorescence intensity was measured using a Tecan M1000 Pro monochromator plate reader, using the automatic gain calculation. $\mathrm{CC}_{50}$ (concentration at $50 \%$ cytotoxicity) values were calculated by curve fitting the inhibition values vs. $\log$ (concentration) and used the sigmoidal dose-response function, with variable fitting values for bottom, top and slope. The curve fitting was implemented using Pipeline Pilot's dose-response component (giving similar results to comparative software such as GraphPad's Prism and IDBS's XlFit).

\subsection{Live cell confocal imaging}

U373MG cells were transferred to $35 \mathrm{~mm}$ Petri Dishes with $12 \mathrm{~mm}$ glass bases (PAA) and grown to $90 \%$ confluence (conditions as described above). Prior to the addition of $5 \mu \mathrm{M}$ TAMRA-labelled peptides and $200 \mathrm{nM}$ Mitotracker ${ }^{\circledR}$ Green FM (Molecular Probes, Invitrogen, Paisley, UK), cells were washed with and transferred into phenol red-free DMEM. During the period of exposure to peptides, cell layers were maintained at $37^{\circ} \mathrm{C}$ in a humidified atmosphere of $5 \% \mathrm{CO}_{2}$. Immediately prior to observation, cells were washed gently $(8 \times)$ and analysed with a Carl Zeiss LSM 880 confocal microscope equipped with a live cell imaging chamber $[26,27]$.

\subsection{Identification and characterisation of antimicrobial peptides}

All antimicrobial assays detailed below were performed by CO-ADD funded by the Wellcome Trust (UK) and The University of Queensland (Australia).

\subsubsection{Primary antimicrobial screening}

To select cationic membrane translocating peptides for further analyses, whole cell growth inhibition assays were performed at a single concentration of $32 \mathrm{mg} / \mathrm{L}$, in duplicate $(\mathrm{n}=2)$. These assays included 5 bacterial pathogens: Escherichia coli, Klebsiella pneumoniae, Acinetobacter baumannii, Pseudomonas aeruginosa and Staphylococcus aureus, and 2 fungi: Candida albicans and Cryptococcus neoformans. Assays were performed as below.

The significance of the inhibition values was determined by modified Z-scores, calculated using the median and MAD of the samples (no controls) on the same plate. Samples with inhibition value above $80 \%$ and Z-Score above 2.5 for either replicate ( $\mathrm{n}=2$ on different plates) were deemed as active. Candidate active antimicrobial peptides were further assayed to ascertain MIC values as described below.

\subsubsection{Sample preparation}

Peptides were prepared to a $10 \mathrm{mg} / \mathrm{mL}$ stock in water and stored at $-20^{\circ} \mathrm{C}$. Peptides were further prepared in water to $32 \mathrm{mg} / \mathrm{L}$ and serially diluted 1:2 fold, 8 times. Each sample concentration was prepared in 384-well plates, non-binding surface plate (Corning 3640) for each bacterial/fungal strain and performed in triplicate $(n=3)$. All the sample preparation was performed using liquid handling robots.

\subsubsection{Antibacterial assays}

All bacteria were cultured in Cation-adjusted Mueller Hinton broth at $37^{\circ} \mathrm{C}$ overnight. A sample of each culture was then diluted 40 -fold in fresh broth and incubated at $37^{\circ} \mathrm{C}$ for $1.5-3 \mathrm{~h}$. The resultant mid-log phase cultures were diluted $\left(\mathrm{CFU} / \mathrm{mL}\right.$ measured by $\left.\mathrm{OD}_{600}\right)$, then added to each well of the compound containing plates, giving a cell density of $5 \times 10^{5} \mathrm{CFU} / \mathrm{mL}$ and a total volume of $50 \mu \mathrm{L}$. All the plates were covered and incubated at $37^{\circ} \mathrm{C}$ for $18 \mathrm{~h}$ without shaking.

Inhibition of bacterial growth was determined measuring absorbance at $600 \mathrm{~nm}\left(\mathrm{OD}_{600}\right)$, using a Tecan M1000 Pro monochromator plate reader. The percentage of growth inhibition was calculated for each well, using the negative control (medium only) and positive control (bacteria without inhibitors) on the same plate as references. The MIC was determined as the lowest concentration at which the growth was fully inhibited, defined by an inhibition $\geq 80 \%$. In addition, the maximal percentage of growth inhibition is reported as DMax, indicating any compounds with partial activity. Hits were classified by $\mathrm{MIC} \leq 16 \mathrm{mg} / \mathrm{L}$.

\subsubsection{Antifungal assays}

Fungi strains were cultured for 3 days on Yeast Extract-Peptone Dextrose agar at $30^{\circ} \mathrm{C}$. A suspension of $1 \times 10^{6}-5 \times 10^{6} \mathrm{CFU} / \mathrm{mL}$ (as determined by $\mathrm{OD}_{530}$ ) was prepared from five colonies. The suspension was subsequently diluted and added to each well of the compound-containing plates giving a final cell density of fungi suspension of $2.5 \times 10^{3} \mathrm{CFU} /$ $\mathrm{mL}$ and a total volume of $50 \mu \mathrm{L}$. All plates were covered and incubated at $35^{\circ} \mathrm{C}$ for $36 \mathrm{~h}$ without shaking.

Growth inhibition of $C$. albicans was determined measuring absorbance at $530 \mathrm{~nm}\left(\mathrm{OD}_{530}\right)$, while the growth inhibition of $C$. neoformans was determined measuring the difference in absorbance between 600 and $570 \mathrm{~nm}\left(\mathrm{OD}_{600-570}\right)$, after the addition of resazurin $(0.001 \%$ final concentration) and incubation at $35^{\circ} \mathrm{C}$ for an additional $2 \mathrm{~h}$ period. The absorbance was measured using a Biotek Synergy HTX plate reader. In both cases, the percentage of growth inhibition was calculated for each well, using the negative control (medium only) and positive control (fungi without inhibitors) on the same plate. The MIC was determined as the lowest concentration at which the growth was fully inhibited, defined by an inhibition $\geq 80 \%$ for $C$. albicans and an inhibition $\geq 70 \%$ for $C$. neoformans. Due to a higher variance in growth and inhibition, a lower threshold was applied to the data for $C$. neoformans. In addition, the maximal percentage of growth inhibition is reported as DMax, indicating any compounds with marginal activity. Hits were classified by MIC $\leq 16 \mathrm{mg} / \mathrm{L}$.

\subsubsection{Antibiotic standards, preparation and quality control (QC)}

Colistin and Vancomycin were used as positive bacterial inhibitor standards for Gram-negative and Gram-positive bacteria, respectively. Fluconazole was used as a positive fungal inhibitor standard for C. albicans and C. neoformans. Tamoxifen was used as a positive cytotoxicity 
standard. Antibiotics were used at 4 concentrations, with 2 above and 2 below its $\mathrm{MIC}$ or $\mathrm{CC}_{50}$ value.

The QC of the assays was determined by the Z'-Factor, calculated from the negative (medium only) and positive controls (bacterial, fungal or cell culture without inhibitor) and the standards. Plates with a Z'-Factor of $\geq 0.4$ and standards active at the highest and inactive at the lowest concentration, were accepted for further data analyses.

\subsection{Statistical analyses}

All statistical analyses were performed using GraphPad Prism 7 software. Results are expressed as mean \pm SEM, unless otherwise stated in the designated figure legend. Comparisons of 3 or more groups of data were performed using one-way ANOVA followed by Dunnett's multiple comparison test to compare experimental values to the identified control. Comparisons of 2 sets of data used Student's $t$-tests. $P$ values were calculated using GraphPad Prism 7 and presented accordingly: $* * * *$, extremely significant, $p<0.0001 ; * * *$, extremely significant, $p=0.0001-0.001 ; * *$, very significant, $p=0.001-0.01 ; *$, significant, $p=0.01-0.05 ; p>0.05$ were deemed statistically insignificant. $\left(H_{0}\right)$;

The presented investigation considers the following Null hypotheses

$H_{01}$ : There is no significant growth inhibition of microbial cells treated with MitP and related analogues compared to cells treated with medium alone.

$H_{02}$ : There is no significant difference in eukaryotic cellular cytotoxicity following treatment with position-14 modified MitP $(\Delta 14 \mathrm{MitP})$ analogues compared to MitP alone.
$H_{03}$ : There is no significant difference in mast cell secretory activity following treatment with $\Delta 14 \mathrm{MitP}$ analogues compared to MitP alone.

\section{Results}

Table 1 highlights the broad range of antibiotic activities of endogenous MPs and structural homologues to date. However, if indeed determined, these peptides clearly exhibit cytotoxicity towards eukaryotic cells and demonstrate mast cell stimulatory properties.

\subsection{Eukaryotic cytotoxicity profiles of $\triangle 14 M i t P$ analogues}

U373MG human astrocytoma cells were used to determine the cytotoxicity profiles of our newly synthesised position-14 modified MitP ( $\Delta 14 \mathrm{MitP}$ ) analogues (Table 2, Fig. 1). We have previously reported that maximum reductions in U373MG cell viability are evident following 4h exposure to MitP and associated analogues [26,31]. Fig. 1 clearly demonstrates that the viability of cells treated with $\left[\mathrm{Ser}^{14}\right] \mathrm{MitP}$, $\left[\mathrm{Orn}^{8}{ }^{8} \mathrm{Ser}^{14}\right] \mathrm{MitP}$ or $\left[\mathrm{Thr}^{14}\right]$ MitP exceeded $80 \%$ even following $4 \mathrm{~h}$ treatment at a final peptide concentration of $30 \mu \mathrm{M}$. Moreover, at a peptide concentration of $30 \mu \mathrm{M}$, all $\Delta 14 \mathrm{MitP}$ analogues demonstrated a reduction in cytotoxicity compared to MitP at the same concentration $(p<0.0001$, Fig. 1).

The rationale for substitution of Leu with Trp at position-14 of MitP was to minimise eukaryotic cell toxicity $[38,39]$. However, and despite a statistically significant reduction in U373MG cytotoxicity when compared to MitP, $30 \mu \mathrm{M}$ [Trp ${ }^{14}$ ] MitP reduced cell viability to $44.3 \%$ when compared to untreated (medium alone) cells $(p<0.0001$, paired $t$-test,

Table 1

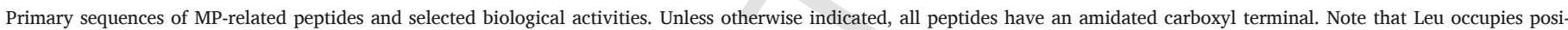

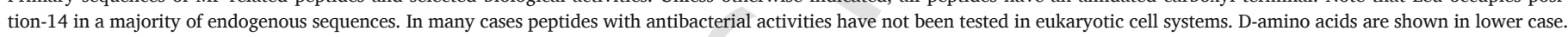
*Indicates an activity that is greatly attenuated compared with other MP analogues. Abbreviations: Adec, 2-amino-decanoamide; Gu, guanidinyl; MC, mast cell; ND, not determined.

\begin{tabular}{|c|c|c|c|c|}
\hline Sequence & Cytotoxicty & & MC secretion & References \\
\hline & Prokaryote & Eukaryote & & \\
\hline \multicolumn{5}{|l|}{ Endogenous peptides } \\
\hline Mastoparan (MP) INLKALAALAKKIL & Gram +, Gram - & Yes & Yes & {$[50]$} \\
\hline$M P-A F$ INLKAIAALAKKLF & Gram - & ND & ND & [70] \\
\hline EMP-AF INLLKIAKGIIKSL & Gram +, Gram - & ND & Yes & {$[50,72]$} \\
\hline MP-B LKLKSIVSWAKKVL & Gram +, Gram - & ND & ND & [53] \\
\hline HR1 INLKALAALVKKVL & Gram + & ND & Yes & [50] \\
\hline MP-VB1 INMKASAAVAKKLL & Gram +, Gram - & Yes & Yes & {$[51]$} \\
\hline$M P-X$ INWKGIAAMAKKLL & Gram +, Gram - & Yes & Yes & {$[57,73]$} \\
\hline MP-S LRLKSIVSYAKKVL & Gram +, Gram - & Yes & ND & [74] \\
\hline Polybia-MP-II INWLKLGKMVIDAL & Gram +, Gram - & Yes & Yes & [51] \\
\hline$P D D-A$ INWKKIFEKVKNLV & Gram +, Gram - & ND & Yes & [75] \\
\hline \multicolumn{5}{|l|}{ Structural homologues } \\
\hline MK4589 INWKKIAKKVAGML & Gram +, Gram - & ND & Yes* & {$[10]$} \\
\hline Gu-MP Gu-INLKALAALAKKIL & Gram - & ND & ND & {$[8]$} \\
\hline Inverso-MP inlkalaalakkil & Gram +, Gram - & Yes & Yes & {$[8,10]$} \\
\hline $\mathrm{MP}-\mathrm{CH}_{2} \mathrm{CH}_{2} \mathrm{NH}_{2}$ INLKALAALAKKIL- $\mathrm{CH}_{2} \mathrm{CH}_{2} \mathrm{NH}_{2}$ & Gram - & ND & ND & {$[10]$} \\
\hline$\left[\right.$ Ala $\left.^{14}\right] M P-X$ INWKGIAAMAKKLA & Gram +, Gram - & ND & ND & {$[57]$} \\
\hline$\left[\right.$ Adec $\left.^{14}\right] M P$ - $X$ INWKGIAAMAKKL(Adec) & Gram +, Gram - & ND & ND & [57] \\
\hline
\end{tabular}

Table 2

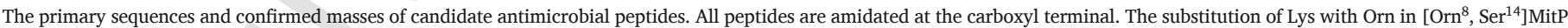
was intended to confer proteolytic resistance whilst maintaining cationic charge density. D-amino acids are written in lower case.

\begin{tabular}{|c|c|c|c|}
\hline Peptide & Sequence & Predicted mW & Confirmed mW \\
\hline$\left[\right.$ Ser $\left.^{14}\right] \mathrm{MitP}$ & $\mathrm{H}$-INLKKLAKL(Aib)KKIS- $\mathrm{NH}_{2}$ & 1581.1 & 1581.0 \\
\hline$\left[\mathrm{Orn}^{8}, \mathrm{Ser}^{14}\right] \mathrm{MitP}$. & $H$-INLKKLA(Orn)L(Aib)KKIS- $\mathrm{NH}_{2}$ & 1567.1 & 1567.1 \\
\hline$\left[\mathrm{Thr}^{14}\right] \mathrm{MitP}$ & $\mathrm{H}$-INLKKLAKL(Aib)KKIT- $\mathrm{NH}_{2}$ & 1595.1 & 1595.0 \\
\hline MitP & $H$-INLKKLAKL(Aib)KKIL- $\mathrm{NH}_{2}$ & 1607.1 & 1607.1 \\
\hline Z-Gly-RGD ${ }^{\mathrm{D}}$ Phe-MitP & Z-GRGDf INLKKLAKL(Aib)KKIL- $\mathrm{NH}_{2}$ & 2273.8 & 2273.5 \\
\hline Z-Gly-RGE ${ }^{\text {DPhe-MitP }}$ & Z-GRGE $f$ INLKKLAKL(Aib)KKIL-NH & 2287.9 & 2287.7 \\
\hline
\end{tabular}

Abbreviations: Aib, 2-aminoisobutyric acid; Orn, ornithine; Z, carboxybenzyl. 


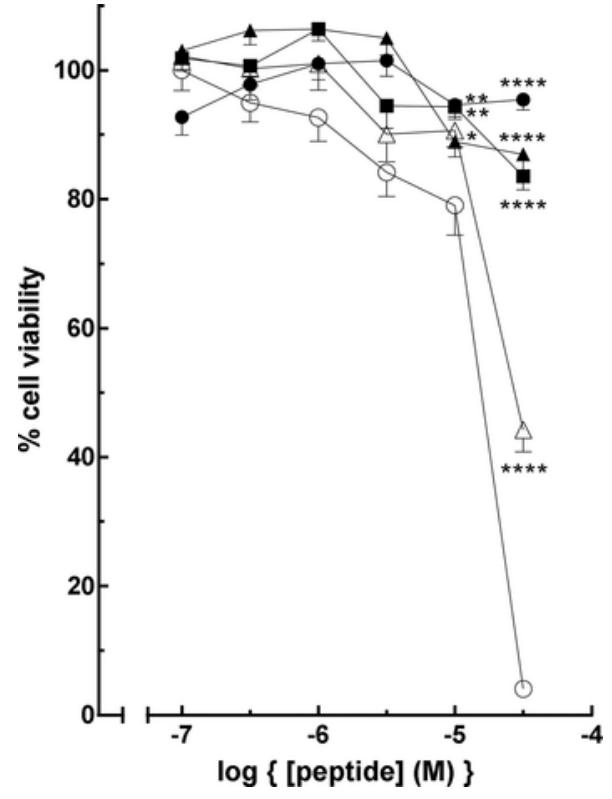

Fig. 1. Comparative eukaryotic cell cytotoxicity profiles of $\Delta 14 \mathrm{MitP}$ analogues. $\Delta 14 \mathrm{MitP}$ analogues demonstrated reduced cytotoxicity of U373MG cells compared to MitP. Cells were treated with $\Delta 14 \mathrm{MitP}$ analogues for $4 \mathrm{~h}$ at the concentrations indicated: $\left[\mathrm{Ser}^{14}\right] \mathrm{MitP}$ (filled square), $\left[\mathrm{Orn}^{8}, \mathrm{Ser}^{14}\right] \mathrm{MitP}$ (filled circle), [Thr $\left.{ }^{14}\right] \mathrm{MitP}$ (filled triangle), $\left[\operatorname{Trp}^{14}\right] \mathrm{MitP}$ (open triangle) and MitP (open circle). Cell viability was measured by MTT conversion and expressed as a percentage of those cells treated with vehicle (medium) alone. Data points are mean \pm SEM from 3 experiments performed in quadruplicate. Statistical analysis: Data were analysed using one-way ANOVA. Post hoc analysis used Dunnett's multiple comparison test to compare viability changes to MitP (positive control) at the corresponding peptide concentrations, $\left(* * * * p<0.0001, * * \mathrm{p}<0.001,{ }^{*} \mathrm{p}<0.05\right)$.

one-tailed) and was therefore deemed to demonstrate cytotoxic effects within eukaryotic cells. MitP was used in this experiment as a positive control and, in accordance with previous findings [26,31] reduced cell viability to $4.1 \%$.

As an additional assessment of potential cytotoxic effects in eukaryotic cells, HEK293 cells were treated with increasing concentrations of ([Ser $\left.\left.{ }^{14}\right] \mathrm{MitP}\right),\left[\mathrm{Orn}^{8}{ }^{8} \mathrm{Ser}^{14}\right] \mathrm{MitP}$ and $\left[\mathrm{Thr}^{14}\right] \mathrm{MitP}$ for $3 \mathrm{~h}$. As with cytotoxicity data using U373MG cells, these peptides were deemed to be inactive giving $\mathrm{CC}_{50}$ values of $>32 \mathrm{mg} / \mathrm{L}$ and gave maximal responses (DMax) which demonstrated a reduction in cytotoxicity compared to MitP $(p<0.0001$, Table 3$)$. In contrast, MitP and target-selective ana-

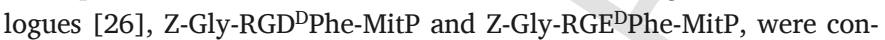
firmed to be cytotoxic in this system giving $\mathrm{CC}_{50}$ values of $\leq 32 \mu \mathrm{g} / \mathrm{mL}$ (Table 3).

\section{Table 3}

Cytotoxicity profiles of candidate cationic CPP using HEK293 cells. $\mathrm{CC}_{50}$ values were determined at the concentration $(\mathrm{mg} / \mathrm{L})$ at which $50 \%$ cytotoxicity occurred in HEK293 cells. $\mathrm{CC}_{50}$ values with $>$ indicate samples with no activity (low DMax value). Cytotoxicity was classified by $\mathrm{CC}_{50} \leq 32 \mu \mathrm{g} / \mathrm{mL}$. DMax indicates maximal response at the highest concentration tested (32 mg/L). Data are expressed as ranges from 2 independent experiments. Data were analysed using one-way ANOVA. Post hoc analysis used Dunnett's multiple comparison test to compare DMax values to those of MitP, $\left({ }^{* * * *} \mathrm{P}<0.0001\right)$.

\begin{tabular}{lll}
\hline Peptide & HEK293 Cytotoxicity & \\
\hline & CC $_{50}(\mathrm{mg} / \mathrm{L})$ & DMax \\
\hline$\left[\right.$ Ser $\left.^{14}\right]$ MitP & $>32$ & {$[14.5,15.5]^{* * * *}$} \\
{$\left[\mathrm{Orn}^{8}\right.$, Ser $\left.^{14}\right]$ MitP } & $>32$ & {$[16.4,18.7]^{* * * *}$} \\
{$\left[\right.$ Thr $\left.^{14}\right]$ MitP } & $>32$ & {$[18.3,19.4]^{* * * *}$} \\
MitP & {$[19.1,20.6]$} & {$[85.4,86.5]$} \\
Z-Gly-RGD & {$[16.7,19.7]$} & {$[96.9,99.9]$} \\
Z-Gly-RGE-MitP & {$[15.3,>32.0]$} & {$[16.4,99.7]$} \\
LRRK2 $^{2413-2427}$ & $>32$ & $19.7]^{* * * *}$ \\
\hline
\end{tabular}

\subsection{Diminished mast cell secretory properties of $\triangle 14 M i t P$ analogues}

RBL-2H3 cells were used as a mucosal mast cell model and secretory events were determined by assaying the exocytosis of the lysosomal marker $\beta$-hexosaminidase. We have previously reported [23] that MitP demonstrates an enhanced secretory efficacy compared to MP. Secretory efficacy indices presented here indicate the above basal activities of peptide analogues as a fraction of that of MP and are determined at a concentration of $30 \mu \mathrm{M}$. Accordingly, MitP gave a secretory efficacy index of 2.83 and $\Delta 14 \mathrm{MitP}$ analogues gave, in descending order, efficacy indices of 1.13 ([Trp $\left.\left.{ }^{14}\right] \mathrm{MitP}\right), 0.79$ ([Thr $\left.\left.{ }^{14}\right] \mathrm{MitP}\right), 0.60$ ([Orn ${ }^{8}$, Ser $\left.\left.^{14}\right] \mathrm{MitP}\right)$ and 0.29 ([Ser $\left.\left.{ }^{14}\right] \mathrm{MitP}\right)$. Fig. 2 shows the concentration-dependent exocytosis of $\beta$-hexosaminidase in response to MitP analogues and further highlights the complete absence of mast cell degranulation in response to treatment with $\left[\mathrm{Ser}^{14}\right] \mathrm{MitP}$, even at a final assay concentration of $30 \mu \mathrm{M}$. Moreover, when comparing secretory efficacies (fold/ basal) at peptide concentrations of $10 \mu \mathrm{M}$ and $30 \mu \mathrm{M}$, all $\Delta 14 \mathrm{MitP}$ analogues demonstrated a significant decrease $(p<0.0001)$ in secretory response compared to MitP at these corresponding concentrations, (Fig. 2).

\subsection{Cellular penetration and mitochondrial accretion of $\triangle 14 M i t P$ analogues}

Considering the probable endosymbiotic origin of mitochondria [28] and the fact that MitP translocates eukaryotic plasma membranes to subsequently and specifically redistribute to mitochondria [26], $\Delta 14 \mathrm{MitP}$ analogues were assessed for their mitochondrial co-localiza-

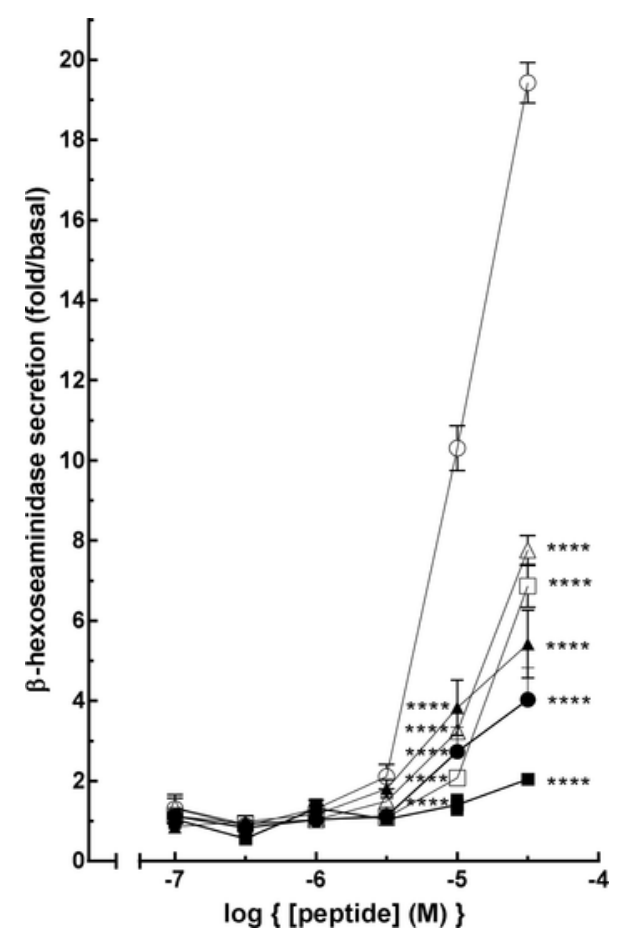

Fig. 2. Comparative secretory activities of $\Delta 14 \mathrm{MitP}$ analogues. $\Delta 14 \mathrm{MitP}$ analogues demonstrated reduced secretory efficacies compared to MitP. RBL-2H3 cells were treated with peptides at the concentrations indicated and medium assayed for the secretory marker $\beta$-hexosaminidase: [Ser $\left.{ }^{14}\right]$ MitP (filled square), $\left[\mathrm{Orn}^{8}, \mathrm{Ser}^{14}\right] \mathrm{MitP}$ (filled circle), $\left[\mathrm{Thr}^{14}\right]$ MitP (filled triangle), $\left[\operatorname{Trp}^{14}\right]$ MitP (open triangle), MP (open square) and MitP (open circle). Data are expressed as fold over basal (medium alone) levels of $\beta$-hexosaminidase secretion and data points are mean \pm SEM from 3 experiments performed in quadruplicate. Data were analysed using one-way ANOVA. Post hoc analysis used Dunnett's multiple comparison test to compare secretory efficacies (fold/basal) to that of MitP (positive control) at the corresponding peptide concentration, $\left({ }^{* * * *} p<0.0001\right)$. 
tion propensity. Fig. 3 indicates that $5 \mu \mathrm{M}$ TAMRA-labelled [Ser $\left.{ }^{14}\right]$ MitP, $\left[\mathrm{Orn}^{8}, \mathrm{Ser}^{14}\right] \mathrm{MitP}$ and $\left[\mathrm{Thr}^{14}\right]$ MitP strongly co-localize with mitochondria in U373MG cells. It is noteworthy that, despite a lack of measured U373MG cellular cytotoxicity, mitochondria demonstrate a condensed morphology following treatment with these analogues (Fig. 3a-c). Moreover, mitochondrial morphology remained unaltered within U373MG cells following treatment with TAMRA-[Trp $\left.{ }^{14}\right] \mathrm{MitP}(5 \mu \mathrm{M})$.
This observation was accompanied by a distinct absence of mitochondrial co-localization. Paradoxically and as stated previously, $\left[\operatorname{Trp}^{14}\right] \mathrm{MitP}$ was the most cytotoxic of all $\Delta 14 \mathrm{MitP}$ analogues reducing cell viability to $44.3 \%(p<0.0001)$ at a maximal peptide concentration of $30 \mu \mathrm{M}$ (Fig. 1). These data indicate that $\left[\operatorname{Trp}^{14}\right]$ MitP-induced cytotoxicity of eukaryotic cells is a likely consequence of random membrane perturbation and not a specific mitochondriotoxic phenomena as

\section{TAMRA-MitP analogue $(5 \mu \mathrm{M})$}

(a)

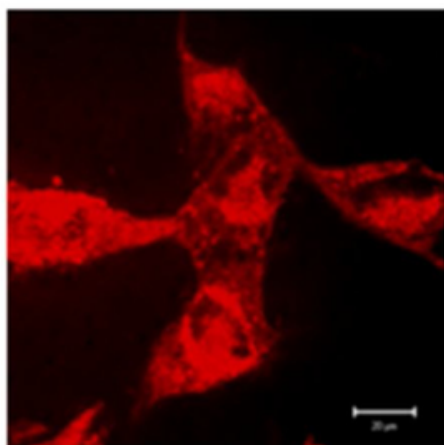

\section{Mitotracker ${ }^{\circledR}$ Green FM (200 nM)}
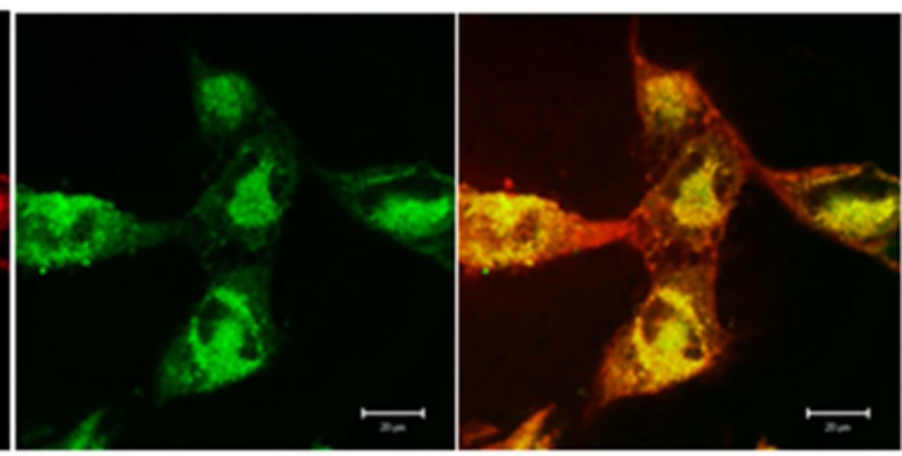

(b)
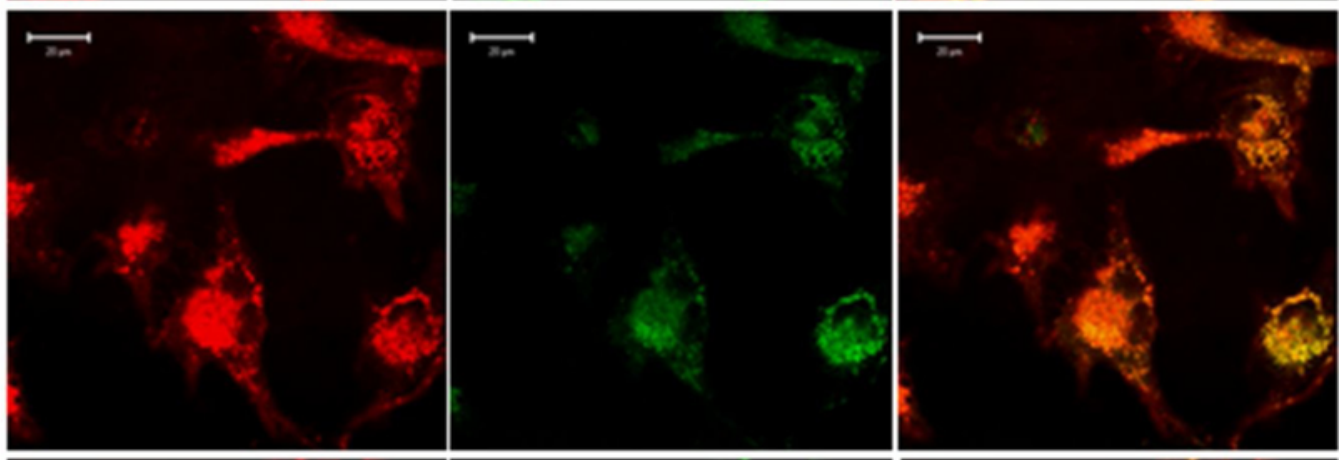

(c)
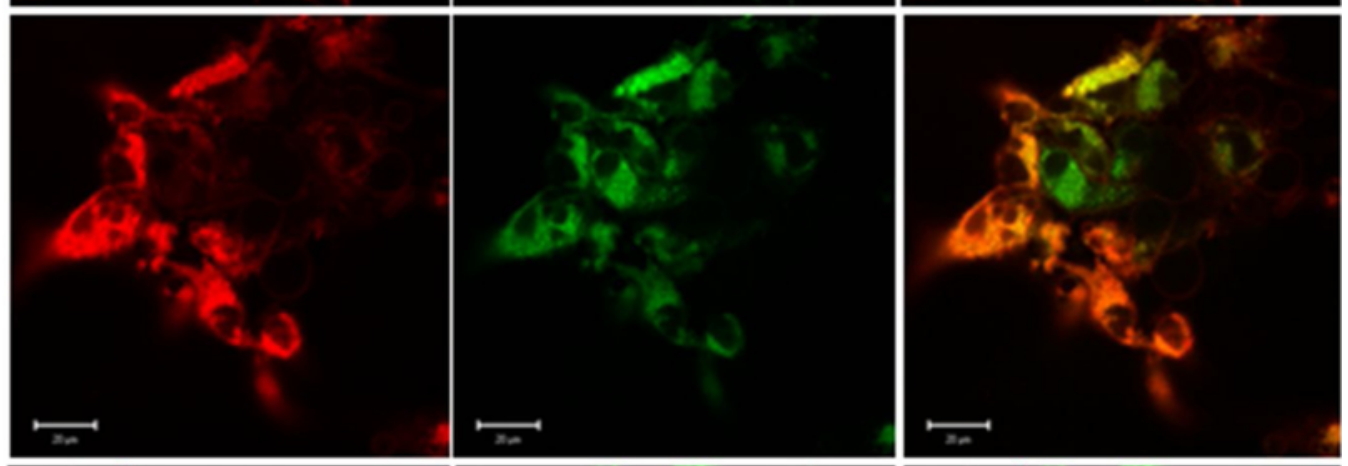

(d)
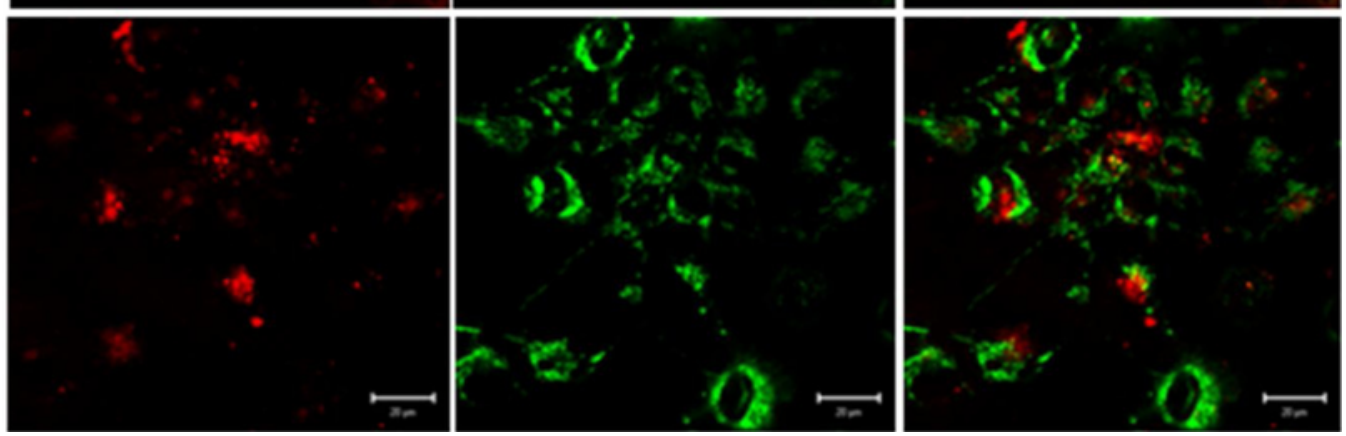

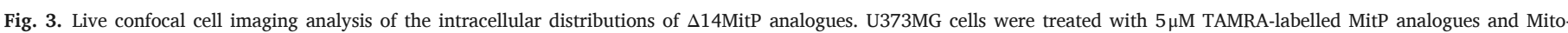

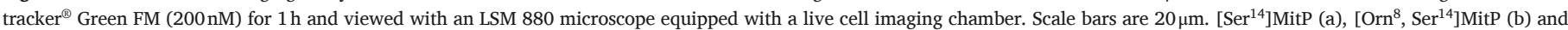

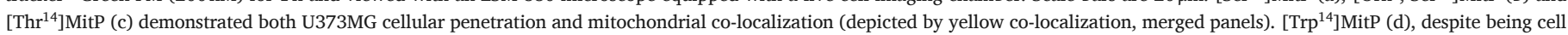
penetrant, did not co-localize with mitochondria. (For interpretation of the references to colour in this figure legend, the reader is referred to the web version of this article.) 
reported for other MitP analogues [26]. Due to its propensity to induce eukaryotic cell death and promote mast cell degranulation comparable to that of MP (Fig. 2), [Trp $\left.{ }^{14}\right]$ MitP was excluded from any further antimicrobial screening.

\subsection{Primary antimicrobial screening and identification of candidate antimicrobials}

Initial screening of a broad range of polycationic cell penetrating peptides (CPPs) was performed at a single peptide concentration of $32 \mathrm{mg} / \mathrm{L}(\mathrm{n}=2)$ and measured inhibition of growth against 5 bacteria; Escherichia coli, Klebsiella pneumoniae, Acinetobacter baumanni, Pseudomonas aeruginosa and Staphylococcus aureus and 2 fungi: Candida albicans and Cryptococcus neoformans. The peptides highlighted in Table 2 were deemed active according to the following criteria; inhibition of bacterial or fungal growth was $\geq 80 \%$ and a Z-score $\geq 2.5$. The target-specific MitP analogues Z-Gly-RGD ${ }^{D}$ Phe-MitP and Z-Gly-RGEDhe-MitP were also included in this study owing to the enhanced propensity of Z-Gly-RGD ${ }^{D}$ Phe-MitP to accrete at mitochondrial membranes [27]. Primary antimicrobial screening further highlighted the antimicrobial potential of the privileged structure that is MP. Accordingly, 6 of the 7 candidate antimicrobials were MP analogues, whereas the remaining 13 polycationic CPP were deemed to be inactive against all organisms included in this study. Inactivity was based on inhibition of bacterial or fungal growth $<80 \%$ or a Z-score of $<2.5$ and was reported for the following polycationic peptides: Sequences derived from human cytochrome $c$ (Cyt $c^{[33]}$ ), Cyt $c^{4-13}\left(\mathrm{H}\right.$-EKGKKIFIMK- $\mathrm{NH}_{2}$ ), Cyt $c^{5-13}\left(\mathrm{H}\right.$-KGKKIFIMK- $\mathrm{NH}_{2}$ ), Cyt $c^{79-88}\left(\mathrm{H}\right.$-KMIFVGIKKK- $\left.\mathrm{NH}_{2}\right)$; a sequence derived from $\mathrm{Na}^{+} \mathrm{K}^{+}$ATPase $\gamma$ ( $H$-LSRRFR(Aib)GGNKKRRQIN- $\mathrm{NH}_{2}$ ); Sequences derived from the leucine rich repeat kinase 2 (LRRK2 ${ }^{[27]}$ ), LRRK2 ${ }^{1322-1340}$ (H-LQQRLKKAVPYNRMKLMIV-NH ${ }_{2}$ ), LRRK2 ${ }^{1546-1564}\left(\mathrm{H}\right.$-PVIDRKRLLQLVRENQLQL- $\mathrm{NH}_{2}$ ), LRRK2 ${ }^{754-755}(\mathrm{H}$-SPKLVELLLNSGSREQDVRKAL- $\mathrm{NH}_{2}$ ), LRRK2 $2^{754-775}$ (P755L) (H-SLKLVELLLNSGSREQD-

Table 4

MICs (mg/L) and DMax values for candidate antimicrobial cationic CPPs.

\begin{tabular}{|c|c|c|c|c|c|c|c|c|c|c|c|c|c|c|}
\hline \multirow[t]{3}{*}{ Peptide } & \multicolumn{14}{|c|}{ Organism } \\
\hline & \multicolumn{2}{|c|}{ S.aureus } & \multicolumn{2}{|c|}{ E.coli } & \multicolumn{2}{|c|}{ K.pneumoniae } & \multicolumn{2}{|c|}{ P.aeruginosa } & \multicolumn{2}{|c|}{ A.baumannii } & \multicolumn{2}{|c|}{ C.albicans } & \multicolumn{2}{|c|}{ C.neoformans } \\
\hline & MIC & DMax & MIC & DMax & MIC & DMax & MIC & DMax & MIC & DMax & MIC & DMax & MIC & DMax \\
\hline$\left[\right.$ Ser $^{14} \mid$ MitP & $>32$ & $\begin{array}{c}19.03 \pm \\
5.31\end{array}$ & $>32$ & $\begin{array}{c}6.13 \pm \\
3.15\end{array}$ & $>32$ & $\begin{array}{c}49.60 \pm \\
1.92\end{array}$ & $>32$ & $\begin{array}{c}16.97 \pm \\
1.01\end{array}$ & $>32$ & $\begin{array}{c}* * * \\
71.34 \pm \\
2.89\end{array}$ & $>32$ & $\begin{array}{c}15.37 \pm \\
7.22\end{array}$ & $\begin{array}{c}5.33 \\
\pm \\
1.33\end{array}$ & $\begin{array}{c}104.23 \pm * \\
2.48\end{array}$ \\
\hline $\begin{array}{l}\text { [Orn } \\
\text { Ser }^{14} \text { |MitP }\end{array}$ & $>32$ & $\begin{array}{c}17.73 \pm \\
3.95\end{array}$ & $>32$ & $\begin{array}{c}4.67 \pm \\
2.33\end{array}$ & $>32$ & $\begin{array}{c}50.63 \pm \\
1.15\end{array}$ & $>32$ & $\begin{array}{c}* * * * \\
76.57 \pm \\
12.53\end{array}$ & $>32$ & $\begin{array}{c}* * * * \\
65.67 \pm \\
3.87\end{array}$ & $>32$ & $\begin{array}{c}11.87 \pm \\
2.41\end{array}$ & $\begin{array}{c}4.00 \\
\pm \\
2.00\end{array}$ & $\begin{array}{c}* * * * \\
97.57 \pm \\
6.94\end{array}$ \\
\hline$\left[\mathrm{Thr}^{14} \mid \mathrm{MitP}\right.$ & $>32$ & $\begin{array}{c}26.93 \pm \\
5.09\end{array}$ & $>32$ & $\begin{array}{c}4.33 \pm \\
2.66\end{array}$ & $>32$ & $\begin{array}{c}67.70 \pm \\
18.79\end{array}$ & $>32$ & $\begin{array}{c}18.07 \pm \\
2.30\end{array}$ & 32 & $\begin{array}{c}* * * * \\
86.27 \pm \\
1.56\end{array}$ & $>32$ & $\begin{array}{c}19.37 \pm \\
13.79\end{array}$ & $\begin{array}{c}3.67 \\
\pm \\
2.19 \\
\end{array}$ & $\begin{array}{c}* * * * \\
105.03 \pm \\
1.28\end{array}$ \\
\hline MitP & $\begin{array}{c}6.67 \\
\pm \\
1.33\end{array}$ & $\begin{array}{c}* * * * \\
98.67 \pm \\
0.82\end{array}$ & $\begin{array}{c}4.00 \pm \\
0.00\end{array}$ & $\begin{array}{c}* * * * \\
99.73 \pm \\
0.3\end{array}$ & $\begin{array}{c}4.00 \pm \\
0.00\end{array}$ & $\begin{array}{c}102.77 \pm \\
0.93\end{array}$ & $\begin{array}{c}16.00 \\
\pm \\
0.00\end{array}$ & $\begin{array}{c}* * * * \\
99.03 \pm \\
0.22\end{array}$ & $\begin{array}{c}0.42 \\
\pm \\
0.08\end{array}$ & $\begin{array}{c}\text { ***** } \\
98.60 \pm \\
1.06\end{array}$ & $\begin{array}{c}21.33 \\
+ \\
5.33\end{array}$ & $\begin{array}{c}* * * * \\
100.5 \pm \\
1.04\end{array}$ & $\begin{array}{c}0.67 \\
\pm \\
0.17\end{array}$ & $\begin{array}{c}* * * * * \\
106.00 \pm \\
2.89\end{array}$ \\
\hline $\begin{array}{l}\text { Z-Gly- } \\
\text { RGD }{ }^{\mathrm{D}} \text { Phe- } \\
\text { MitP }\end{array}$ & $\begin{array}{c}6.67 \\
\pm \\
1.33\end{array}$ & $\begin{array}{c}* * * * * \\
96.23 \pm \\
1.07\end{array}$ & $\begin{array}{c}4.00 \pm \\
0.00\end{array}$ & $\begin{array}{c}* * * * \\
97.63 \pm \\
0.50\end{array}$ & $\begin{array}{l}26.67 \\
\pm 5.33\end{array}$ & $\begin{array}{c}* * * \\
81.23 \pm \\
17.57\end{array}$ & $>32$ & $\begin{array}{c}78.40 \pm \\
17.55\end{array}$ & $\begin{array}{c}0.83 \\
\pm \\
0.17\end{array}$ & $\begin{array}{c}\text { **** } \\
97.30 \pm \\
0.94\end{array}$ & $\begin{array}{c}13.33 \\
+ \\
2.67\end{array}$ & $\begin{array}{c}* * * * \\
99.13 \pm \\
1.49\end{array}$ & $\begin{array}{c}1.33 \\
\pm \\
0.33\end{array}$ & $\begin{array}{c}* * * * \\
104.43 \pm \\
1.71\end{array}$ \\
\hline $\begin{array}{l}\text { Z-Gly- } \\
\text { RGED'Phe- } \\
\text { MitP }\end{array}$ & $\begin{array}{c}8.00 \\
\pm \\
0.00\end{array}$ & $\begin{array}{c}* * * * \\
96.03 \pm \\
0.29\end{array}$ & $\begin{array}{l}5.33 \pm \\
1.33\end{array}$ & $\begin{array}{c}* * * * \\
98.17 \pm \\
0.14\end{array}$ & $\begin{array}{l}26.67 \\
\pm 5.33\end{array}$ & $\begin{array}{c}60.83 \pm \\
20.56\end{array}$ & 32 & $\begin{array}{c}91.80 \pm \\
4.75\end{array}$ & $\begin{array}{c}0.83 \\
\pm \\
0.17\end{array}$ & $\begin{array}{c}* * * * \\
96.40 \pm \\
1.27\end{array}$ & $\begin{array}{c}8.00 \\
+ \\
0.00\end{array}$ & $\begin{array}{c}* * * * * \\
100.53 \pm \\
1.22\end{array}$ & $\begin{array}{c}0.67 \\
\pm \\
0.17\end{array}$ & $\begin{array}{c}* * * * \\
104.77 \pm \\
2.54\end{array}$ \\
\hline LRRK2 $^{2+13-2427}$ & $>32$ & $\begin{array}{c}29.07 \pm \\
4.47\end{array}$ & $>32$ & $\begin{array}{c}-2.13 \pm \\
3.492\end{array}$ & $>32$ & $\begin{array}{c}15.33 \pm \\
3.88\end{array}$ & $>32$ & $2.13 \pm 2.30$ & $>32$ & $\begin{array}{c}18.03 \pm \\
11.55\end{array}$ & $>32$ & $\begin{array}{c}39.23 \pm \\
2.62\end{array}$ & $\begin{array}{c}12.00 \\
\pm \\
4.00\end{array}$ & $\begin{array}{c}* * * * \\
102.90 \pm \\
1.20\end{array}$ \\
\hline
\end{tabular}

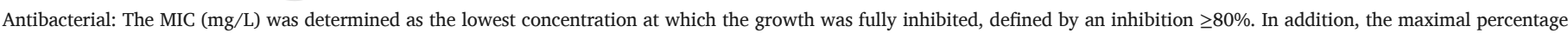
of growth inhibition is reported as DMax (maximal response), which additionally indicates any compounds with partial activity at the maximum screened concentration (32mg/L).

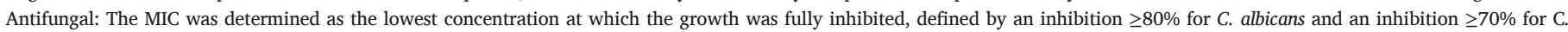
neoformans. In addition, the maximal percentage of growth inhibition is reported as DMax, indicating any compounds with marginal activity.

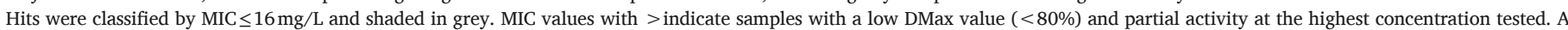

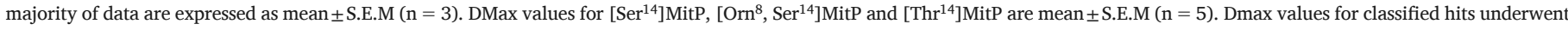

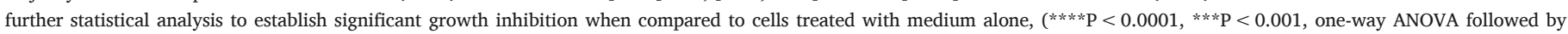
Dunnett's multiple comparison test).
VRKAL- $\left.\mathrm{NH}_{2}\right), \quad\left[\mathrm{DArg}^{1}, \quad \mathrm{Aib}^{12}\right]$ LRRK2 ${ }^{2413-2427} \quad(H$-rVKTLCLQKNT(Aib)LWI- $\mathrm{NH}_{2}$ ), $\quad$ LRRK2 ${ }^{1116-1136}$ (H-GNKISGICSPLRLKELKILNL- $\mathrm{NH}_{2}$ ), LRRK2 $2^{1367-1386}$ (H-ATVGIDVKDWPIQIRDKRKR- $\mathrm{NH}_{2}$ ), LRRK2 $2^{1367-1386}$ (I1371 V)Mut (H-ATVGVDVKDWPIQIRDKRKR- $\mathrm{NH}_{2}$ ), and a sequence derived from the eye-specific ovo transcription factor of the planarian Schmidtea mediterranea (H-IVKTIKVKRRNFAEYIKKL- $\mathrm{NH}_{2}$ ).

\subsection{MIC and DMax values of candidate antibacterial agents}

MICs were determined as the lowest concentration at which growth was fully inhibited and defined by an inhibition $\geq 80 \%$, (Table 4 ). MitP, according to the criteria stipulated in Table 4 (MIC $\leq 16 \mathrm{mg} / \mathrm{L}$ ) demonstrated activity against all 5 bacteria, Z-Gly-RGD ${ }^{\text {Phe-MitP was }}$

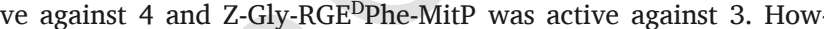
mote mast cell secretion (Fig. 2) and induce death of eukaryotic cells (Fig. 1), gave high MIC values $(\geq 32 \mathrm{mg} / \mathrm{L}$, the highest concentration tested), (Table 4). Nonetheless, $\Delta 14 \mathrm{MitP}$ analogues inhibited the growth of $A$. baumannii by maximum mean values of $86.27 \%$ ([Thr $\left.{ }^{14}\right] \mathrm{MitP}$ ), 71.34\% ([Ser $\left.\left.{ }_{14}\right] \mathrm{MitP}\right)$ and $65.67 \%\left(\left[\mathrm{Orn}^{8}, \mathrm{Ser}^{14}\right] \mathrm{MitP}\right)$ when compared to control cells treated with medium alone, $(\mathrm{P}<0.0001$, ANOVA and post hoc Dunnett's comparison, Table 4). It is thus tempting to specthat other amino acid substitution at position-14 of MitP might ( Additionally, and using the same statistical analysis as above, [Orn ${ }^{8}$, MitP exhibited a mean maximal inhibitory growth response of

MICs were determined as the lowest concentration at which growth was fully inhibited and defined by an inhibition $\geq 80 \%$ for $C$. albicans 3.6. MIC values of candidate antifungal agents 
and an inhibition $\geq 70 \%$ for $C$. neoformans. Table 4 highlights that all $\triangle 14 \mathrm{MitP}$ analogues were deemed active against $C$. neoformans, giving MIC (mg/L) values of 3.67, 4.00 and 5.33 for [Thr $\left.{ }^{14}\right] \mathrm{MitP}$, [Orn ${ }^{8}$, Ser $\left.{ }^{14}\right]$ MitP and $\left[\right.$ Ser $\left.^{14}\right]$ MitP, respectively.

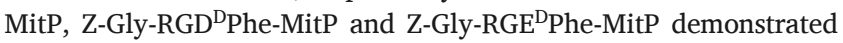
activity against both $C$. neoformans and C. albicans, whilst LRRK2 ${ }^{2413-2427}$ was active against C. neoformans (Table 4). This latter peptide was also confirmed to be non-cytotoxic in HEK293 cells (Table 3).

\section{Discussion}

Examples of endogenous peptide antibiotics are currently numbered in their thousands [40-42]. Considering the pressing need to identify entirely new classes of antibiotic, particularly agents active against Gram-negative organisms [43], peptides extracted from natural sources, including those isolated from animal venoms [44,45], are a valuable commodity. As described herein (Table 1), wasp venoms from many species contain significant amounts of a MP peptide that, following envenomation, rapidly induces dolor, rubor, calor and tumor; four classic symptoms of acute inflammation. The common privileged structure of MP peptides, mirrored in part by the mitochondriotoxic MitP, enables this genus of peptides to cross biological membranes and regulate the activities of protein targets that include heterotrimeric $G$ proteins [3,14-6]. This localized receptor-independent activation of MC secretion, the primary response driving adverse reactions to wasp stings, is a major caveat to the therapeutic utility of most MP-related cationic sequences Thus, a major objective of this study was to introduce minor changes to the scaffold structure of MitP in order to maintain membrane translocating activity but to reduce or negate both MC secretion and eukaryotic cell toxicity.

Of particular relevance to this study, many MP peptides have antimicrobial activities (Table 1) and there are other pertinent examples of cationic $\alpha$-helical peptide antibiotics which include the magainins and cercopins [42]. As noted by others [46], the ability to cross or intercalate into a biological membrane is a common feature of both cationic cell penetrating peptides (CPPs) and many antibiotic peptides. Moreover, we would classify antibiotic MP analogues as bioportides, a designated class of bioactive CPPs distinct from inert delivery vectors $[47,48]$. As described and presented herein (Table 4), MitP is a broad-spectrum antimicrobial and could have utility for non-medical applications such as aquaculture and domestic usage. Moreover, the extensive structure activity relationships of endogenous and synthetic MP analogues indicated that it could be possible to engineer novel analogues of MitP devoid of undesirable biological activities. For example, the synthetic MP analogue $\left[\mathrm{Lys}^{10}{ }^{10}\right.$ Leu $\left.^{13}\right]$ MP (mas 11) lacks the usual lytic activity of MP peptides but is a more potent activator of secretion from rodent peritoneal MCs [49]. Hence, we chose to modify the carboxyl terminal of MitP, usually occupied by the hydrophobic residue leucine, with other natural amino acids. For example, the substitution of serine into position-14 directs a polar hydroxyl group at the distal end of the hydrophobic face of [Ser $\left.{ }^{14}\right]$ MitP when modelled as a $3.6_{13} \alpha$-helix, (Fig. 4).

A common biological activity of MP peptides is the ability to promote cell lysis or, more specifically, haemolysis [41,42,50-53]. This disruption of biological membranes by cationic peptides has been widely proposed as a general mechanism of antibiotic activity. Both MP and HR1 (Table 1) may accumulate on the outer surface of biological membranes and promote membrane breakdown by the carpet mechanism [50,54]. Accordingly, electrostatic interactions between $\alpha$-helical cationic peptides and negatively charged membrane components promote peptide accumulation at the membrane surface [55,56]. At a critical concentration sufficient peptide, bound in an orientation that is parallel to the membrane surface, "carpets" the bilayer to promote membrane disintegration by a detergent-like mechanism. Clearly, the additional Lys residues added to the privileged scaffold of MitP analogues (Fig. 4) would favour a molecular interaction with more anionic bacterial membranes compared with more zwitterionic eukaryotic plasma membranes [50,52]. However, a variety of alternative membrane permeation mechanisms are possible $[41,42,55,56]$ that may also contribute to the molecular basis of membrane selectivity and antimicrobial activity observed amongst some MP peptides [50,55,57]. We anticipate that future studies will more clearly define the antimicrobial mechanism of action of MitP analogues and such data will provide guidelines for the engineering of second generation $\Delta 14 \mathrm{MitP}$ analogues.

The privileged structure of MP and related sequences is readily modified either during or post synthesis and single amino acid substitutions within a tetradecapeptide helix can produce dramatic changes in biological activities [52-54] and/or membrane selectivity (Fig. 4). Of particular relevance to this study, the substitution of Ala at position-14 in MP-X ([Ala $\left.{ }^{14}\right]$ MP-X; Table 1 ) resulted in a higher specificity for red blood cell membranes compared with bacteria [57]. Similar substitution with the more hydrophobic amino acid 2-amino-decanoic acid ([Adec $\left.{ }^{14}\right] \mathrm{MP}-\mathrm{X}$; Table 1) increased bactericidal potency but reduced membrane selectivity [57]. As exemplified by the collective biological activities of $\Delta 14 \mathrm{MitP}$ analogues, perturbation of the tertradecapeptide amphipathic helical structure can diminish some undesirable properties of the parent compounds whilst maintaining promising antimicrobial activities. For example, [Ser $\left.{ }^{14}\right]$ MitP entirely lacks the capacity of MitP and target-selective analogues to promote MC degranulation and is essentially non-toxic when applied to eukaryotic cells, (Figs. 1 and 2, Table 3). Our studies also confirmed (Fig. 3d) that $\left[\mathrm{Ser}^{14}\right] \mathrm{MitP}$ is an efficient CPP and, in common with MitP and some other analogues, accumulates within mitochondria following efficient cellular entry. Significantly, the mitochondrial accretion of [Ser $\left.{ }^{14}\right] \mathrm{MitP}$ does not induce cell death by intrinsic apoptosis or other mechanisms. Considering the ubiquitous contribution of mitochondrial membrane permeabilisation in the end stages of eukaryotic cell death [58], this observation clearly indicates that the substitution of a polar residue at position-14 in [Ser $\left.{ }^{14}\right]$ MitP does not prevent mitochondrial membrane accumulation but negates the activation of the voltage-dependent anion channel (VDAC) which leads to the release of apoptogenic cytochrome $c$ from mitochondria [26]. This observation also alludes to the possibility of using MitP analogues to target intracellular microorganisms without detriment to the host cell. In contrast, $\left[\operatorname{Trp}^{14}\right]$ MitP displays significant cytotoxicty in eukaryotic cell systems (Fig. 1) and it was therefore initially predicted that $\left[\operatorname{Trp}^{14}\right] \mathrm{MitP}$, as is the case with MitP, was inducing late intrinsic apoptotic events through cooperation with the permeability transition pore-associated protein VDAC, with a consequential release of cytochrome $c$ and activation of the caspase cascade [26]. However, live confocal cell imaging analysis (Fig. 3D) clearly demonstrates that $\left[\operatorname{Trp}^{14}\right]$ MitP does not accrete within mitochondrial membranes and therefore suggests, particularly within a $4 \mathrm{~h}$ incubation period, a necrotic mechanism of cell death, such as induction of non-specific perturbations of the plasma membrane as is the case with high concentrations $(>20 \mu \mathrm{M})$ of many MP analogues $[10,23,31,50]$.

If general membrane perturbation is a common mechanism of action of antimicrobial MitP analogues, then structural or biochemical differences between mitochondrial, bacterial and fungal membranes might provide some explanation for the distinct activity profiles of peptides characterised and described herein. There is superficial ultrastructural similarity between the double membrane systems of the eukaryotic mitochondrion and Gram-negative bacteria including A. baumannii. Mitochondrial membranes are composed of all of the major classes of phospholipids that constitute eukaryotic plasma membranes, with the addition of small quantities of cardiolipin [59]. Moreover, the mito- 


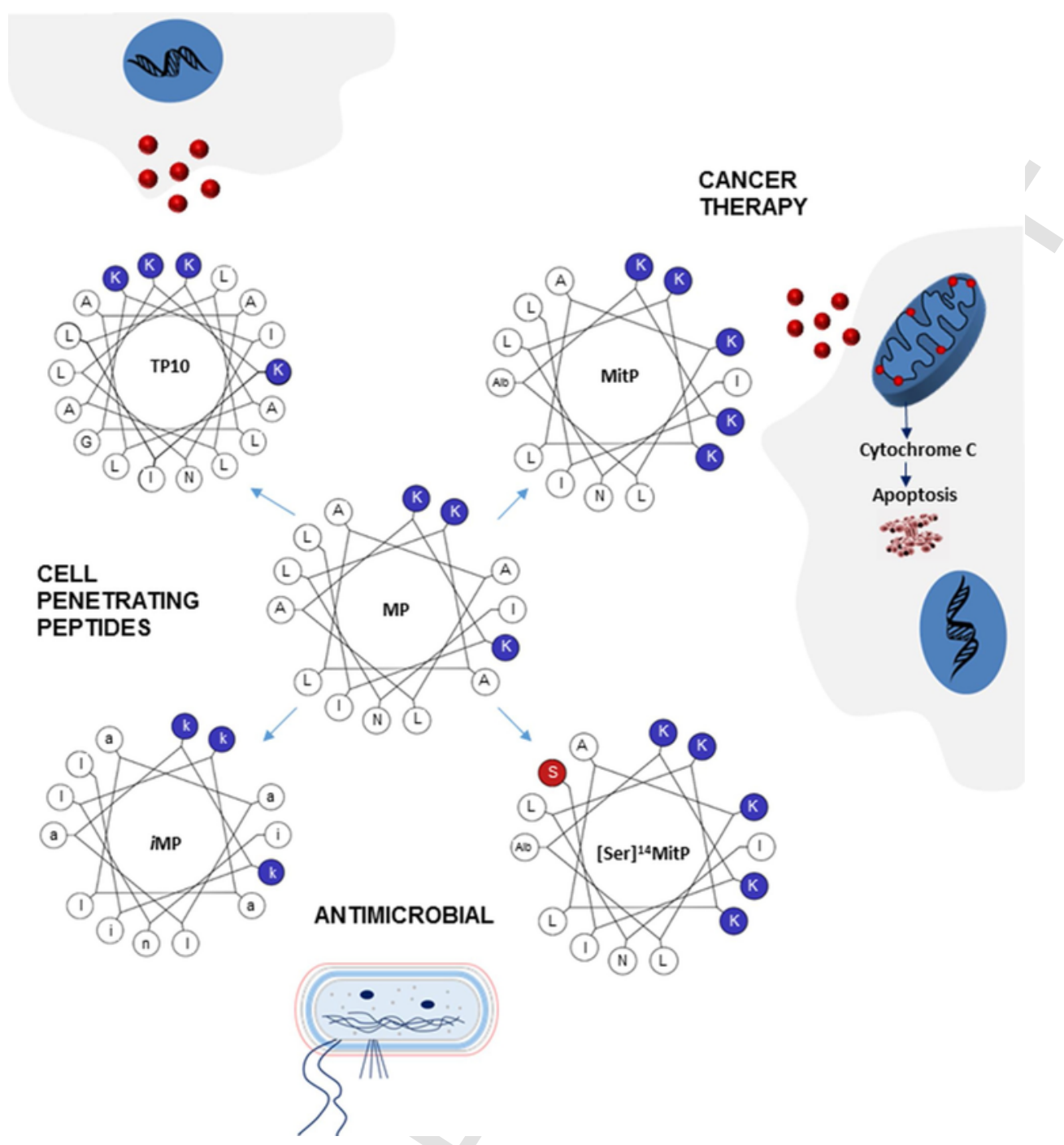

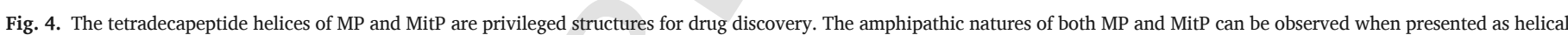

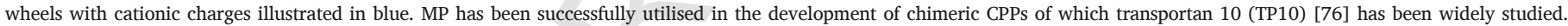

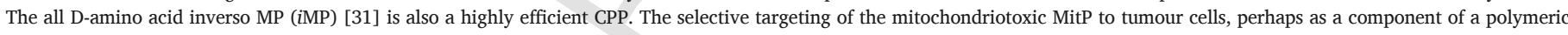

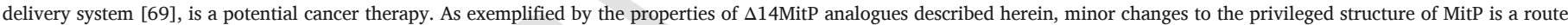

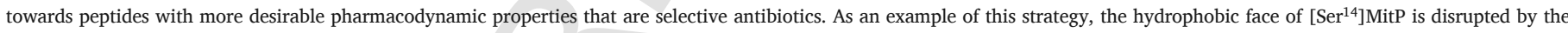
polar side chain of Ser indicated in red. (For interpretation of the references to colour in this figure legend, the reader is referred to the web version of this article.)

chondrial outer membrane, the presumed initial site of accretion of some but not all MitP analogues is a relatively simple phospholipid bilayer enriched in porin proteins. Conversely, the bacterial cell envelope is a more variable and complex multi-layered structure [60]. The outer membrane $(\mathrm{OM})$, a distinguishing feature of Gram-negative bacteria, is not a phospholipid bilayer but is predominantly composed of glycolipids, principally the highly immunogenic lipopolysaccharide. A majority of proteins located within the OM comprise either lipoproteins or others of a $\beta$-barrel tertiary structure including porins $[60,61]$. It is noteworthy that, when screening a total of 15 antimicrobial peptides, melittin, indolicidin and MP were identified as being effective against both colistin-susceptible and colistin-resistant $A$. baumannii [8]. The potential importance of the further development of $\Delta 14 \mathrm{MitP}$ analogues to combat A. baumannii infections, particularly in immunosuppressed patients, is amplified by the identification of colistin-resistant $A$. baumannii clinical isolates at the start of the new millennium [62]. Our data provide hope that other $\Delta 14 \mathrm{MitP}$ analogues might display enhanced activities against $A$, baumannii and other pathogenic bacteria whilst maintaining the desirable properties of [Ser $\left.{ }^{14}\right]$ MitP in eukaryotic cell systems.
In common with the cell envelopes of bacteria, the composition of fungal cell walls is also highly variable, structurally unique and primarily composed of glycoproteins and polysaccharides [63]. There is no double membrane system but, in order to access the plasma membrane of fungi, antimicrobial peptides must cross a dynamic cell wall that functions to maintain the structural integrity and metabolic function of the eukaryotic cell [63]. Indeed, there are major compositional differences in the various layers of the cell wall of Candida and Cryptococcus species, the latter being surrounded by a relatively thick polysaccharide capsule that can inhibit the function of phagocytes [64]. We were, therefore, surprised to observe that a larger variety of screened peptides, including all MitP analogues and an unrelated cationic sequences from LRRK2, were active against C. albicans and/or C. neoformans. The $\Delta 14 \mathrm{MitP}$ analogues are particularly promising and relatively selective antifungal agents. These findings also suggest that cationic CPP may induce fungal cell death by a common mode of action that is distinct from that of agents which target sterols or target cell wall synthesis [65]. Since a majority of $C$. neoformans infections take place in the lungs of immunocompromised patients [66], there is clearly scope to 
develop non-secretory analogues of MitP for topical application perhaps combined with anti-HIV medications.

\section{Conclusions}

Collectively, our data indicate that MitP is a viable template for the development of unique antibiotic peptides. It is now clear that relatively minor changes to the core tetradecaptide sequence of either MP or MitP can lead to distinct changes in activity. Furthermore, our studies with $\Delta 14$ MitP analogues have illustrated an effective route towards the development of antimicrobials that lack detrimental activities against eukaryotic cells. Molecular modelling, using computational algorithms to define quantitative structure-activity relationships (QSAR) $[67,68]$, could be a useful strategy to further engineer MitP peptides. The oral bioavailability of such peptides could be addressed by the incorporation of D-amino acids [56] or unnatural moieties [57] at labile sites such as between position $\mathrm{I}^{1}$ and $\mathrm{N}^{2}$ [8]. Many other structural modifications to the privileged scaffold are also feasible [48], and more sophisticated strategies could be utilised to selectively deliver antibiotic peptides to the sites of human infection [48]. Of particular relevance to this study, a polymeric delivery system has been developed [69] to direct MitP to human tumours. Self-assembled nanoparticles of cationic antibiotic peptides, designed to disintegrate in contact with an anionic bacterial cell surface, might also be adapted to deliver MitP analogues in vivo [70]. Finally, $\Delta 14 \mathrm{MitP}$ analogues could be combined with other clinically useful antibiotics to improve efficacy and combat multiple-antibiotic-resistant strains of bacteria and fungi [71].

\section{Funding}

This research did not receive any specific grant from funding agencies in the public, commercial, or not-for-profit sectors.

\section{Conflict of interest}

The authors declare no conflict of interest.

\section{Acknowledgements}

We are extremely grateful for the support provided by the Community for Antimicrobial Drug Discovery. We also thank Professor Jerzy Silberring, AGH University of Science and Technology, Kraków, for the mass spectral analyses of some peptides reported in this study.

\section{References}

[1] R.J. Lewis, M.L. Garcia, Therapeutic potential of venom peptides, Nat. Rev. Drug Discov. 2 (2003) 790-802.

[2] Y. Hirai, T. Yasuhara, H. Yoshida, T. Nakajima, M. Fujino, C. Kitada, A new mast cell degranulating peptide mastoparan in the venom of Vespula lewisii, Chem. Pharm. Bull. (Tokyo) 27 (1979) 1942-1944.

[3] T. Higashijima, S. Uzu, T. Nakajima, E.M. Ross, Mastoparan, a peptide toxin from wasp venom, mimics receptors by activating GTP-binding regulatory proteins (G proteins), J. Biol. Chem. 263 (1988) 6491-6494.

[4] B.E. Evans, K.E. Rittle, M.G. Bock, R.M. DiPardo, R.M. Freidinger, W.L. Whitter, G.F. Lundell, D.F. Veber, P.S. Anderson, Methods for drug discovery: development of potent selective, orally effective cholecystokinin antagonists, J. Med. Chem. 31 (1988) 2235-2246.

[5] M.E. Welsch, S.A. Snyder, B.R. Stockwell, Privileged scaffolds for library design and drug discovery, Curr. Opin. Chem. Biol. 14 (2010) 347-361.

[6] Y. Che, G.R. Marshall, Privileged scaffolds targeting reverse-turn and helix recognition, Expert Opin. Ther. Targets 12 (2008) 1-14.

[7] P. Cherkupally, S. Ramesh, Y.E. Jad, T. Govender, H.G. Kruger, Cyclic peptides as privileged structures, in: S. Bräse (Ed.), Privileged Scaffolds in Medicinal Chemistry: Design, Synthesis, Evaluation. RSC Drug Discovery Series No. 50, Royal Society of Chemistry, Cambridge, UK, 2016, pp. 398-438.

[8] X. Vila-Farrés, R. López-Rojas, M.E. Pachón-Ibáñez, M. Teixidó, J. Pachón, J. Vila, E. Giralt, Sequence-activity relationship, and mechanism of action of mastoparan analogues against extended-drug resistant Acinetobacter baumannii, Eur. J. Med. Chem. 101 (2015) 34-40.
[9] K. Konno, M. Hisada, H. Naoki, Y. Itagaki, N. Kawai, A. Niwa, T. Yasuhara, Y. Morimoto, Y. Nakata, Structure and biological activities of eumenine mastoparan-AF (EMP-AF), a new mast cell degranulating peptide in the venom of the solitary wasp (Anterhynchium flavomarginatum micado), Toxicon 38 (2000) 1505-1513.

[10] B.M. Souza, M.P. Cabrera, P.C. Gomes, N.B. Dias, R.G. Stabeli, N.B. Leite, J.R. Neto, M.S. Palma, Structure-activity relationship of mastoparan analogs: effects of the number and positioning of lys residues on secondary structure, interaction with membrane-mimetic systems and biological activity, Peptides 72 (2015) 164-174.

[11] T. Higashijima, K. Wakamatsu, M. Takemitsu, M. Fujino, T. Nakajima, T. Miyazawa, Conformational change of mastoparan from wasp venom on binding with phospholipid membrane, FEBS Lett. 152 (1983) 227-230.

[12] Y. Hori, M. Demura, M. Iwadate, A.S. Ulrich, T. Niisome, H. Aoyagi, T. Asakura, Eur. J. Biochem. 268 (2001) 302.

[13] M. Sukumar, T. Higashijima, G protein-bound conformation of mastoparan-X, a receptor-mimetic peptide, J. Biol. Chem. 267 (1992) 21421-21424.

[14] M. Sukumar, E.M. Ross, T. Higashijima, A Gs-selective analog of the receptor-mimetic peptide mastopoan binds to Gs $\alpha$ in a kinked helical conformation, Biochemistry 36 (1997) 3632-3639.

[15] S. Jones, J. Howl, Biological applications of the receptor mimetic peptide mastoparan, Curr. Protein Pept. Sci. 7 (2006) 501-508.

[16] S. Jones, J. Howl, Mastoparans, in: J. Howl, S. Jones (Eds.), Bioactive Peptides, CRC Press, Boca Raton, USA, 2009, pp. 429-445.

[17] C.L. Longland, M. Mezna, Ü. Langel, M. Hällbrink, M. Wheatley, F. Michelangeli, J. Howl, Biochemical mechanisms of calcium mobilisation induced by mastoparan and chimeric hormone-mastoparan constructs, Cell Calcium 24 (1988) 27-34.

[18] D.A. Malencik, S.R. Anderson, High affinity binding of the mastoparans by calmodulin, Biochem. Biophys. Res. Commun. 114 (1983) 50-56.

[19] Y. Hirata, M. Atsumi, Y. Ohizumi, N. Nakahata, Mastoparan binds to glycogen phosphorylase to regulate sarcoplasmic reticular $\mathrm{Ca}^{2+}$ release in skeletal muscle, Biochem. J. 371 (2003) 81-88.

[20] T. Higashijima, J. Burnier, E. Ross, Regulation of Gi and Go by mastoparan related amphiphilic peptides, and hydrophobic amines. Mechanism and structural determinants of activity, J. Biol. Chem. 265 (1990) 14176-14186.

[21] C. Oppi, T. Wagner, A. Crisari, B. Camerini, G.P. Tocchini Valentini, Attenuation of GTPase activity of recombinant G(o) alpha by peptides representing sequence permutations of mastoparan, Proc. Natl. Acad. Sci. U. S. A. 89 (1992) 8268-8272.

[22] R. Weingarten, L. Ransnas, H. Mueller, L.A. Sklar, G.M. Bokoch, Mastoparan interacts with the carboxyl terminus of the alpha subunit of Gi, J. Biol. Chem. 265 (1990) 11044-11049.

[23] S. Jones, J. Howl, Charge delocalisation and the design of novel mastoparan analogues: enhanced cytotoxicity and secretory efficacy of [Lys5 Lys8, Aib10]MP, Regul. Pept. 121 (2004) 121-128.

[24] J. Howl, Z. Prochazka, M. Wheatley, J. Slaninová, Novel strategies for the design of receptor-selective vasopressin analogies: aib-substitution and retro-inverso transformation, Br. J. Pharmacol. 128 (1999) 647-652.

[25] I.L. Karle, Helix promoters, non-natural residues, retro peptides and non-peptide inserts, in: P.T.P. Kaumaya, R.S. Hodges (Eds.), Peptides: Chemistry, Structure and Biology, Mayflower Scientific, Kingswinford, UK, 1996, pp. 543-545.

[26] S. Jones, C. Martel, A.-S. Belzaca-Casagrande, C. Brenner, J. Howl, Mitoparan and target-selective chimeric analogues: membrane translocation and intracellular redistribution induces mitochondrial apoptosis, Biochim. Biophys. Acta 1783 (2008) 849-863.

[27] S. Jones, J. Uusna, Ü. Langel, J. Howl, Intracellular target-specific accretion of cell penetrating peptides and bioportides: ultrastructural and biological correlates, Bioconj. Chem. 27 (2016) 121-129.

[28] L. Margulis, Origin of Eukaryotic Cells, Yale University Press, USA, 1971.

[29] J. Howl, S. Jones, Cell penetrating peptide-mediated transport enables the regulated secretion of accumulated cargoes from mast cells, J. Control. Release 201 (2015) 108-117.

[30] S.A. Palasek, Z.J. Cox, J.M. Collins, Limiting racemization and aspartimide formation in microwave-enhanced Fmoc solid phase peptide synthesis, J. Pept. Sci. 13 (2007) 143-148.

[31] S. Jones, J. Howl, Enantiomer-specific bioactivities of peptidomimetic analogues of mastoparan and mitoparan: characterization of inverso mastoparan as a highly efficient cell penetrating peptide, Bioconj. Chem. 23 (2012) 47-56.

[32] E. Passante, N. Frankish, The RBL-2H3 cell line: its provenance and suitability as a model for the mast cell, Inflamm. Res. 58 (2009) 737-745.

[33] S. Jones, T. Holm, I. Mäger, Ü. Langel, J. Howl, Characterization of bioactive cell penetrating peptides from human cytochrome c: protein mimicry and the development of a novel apoptogenic agent, Chem. Biol. 17 (2010) 735-744.

[34] M. Farquhar, U. Soomets, R.L. Bates, A. Martin, Ü. Langel, J. Howl, Novel mastoparan analogs induce differential secretion from mast cells, Chem. Biol. 9 (2002) 63-70.

[35] J. Howl, S. Jones, M. Farquhar, Intracellular delivery of bioactive peptides to RBL-2H3 cells induces B-hexoseaminidase secretion and phospholipase D activation, ChemBioChem 4 (2003) 1312-1316.

[36] J. Senshyn, R.A. Baumgartner, M.A. Beaven, Quercetin sensitizes RBL-2H3 cells to polybasic mast cell secretagogues through increased expression of Gi GTP-binding proteins linked to a phospholipase C signalling pathway, J. Immunol. 160 (1998) 5136-5144.

[37] J. Carmichael, W.G. DeGraff, A.F. Gazdar, J.D. Minna, J.B. Mitchell, Evaluation of a tetrazolium-based semiautomated colorimetric assay: assessment of chemosensitivity testing, Cancer Res. 47 (1987) 936-942.

[38] L. Crombez, G. Aldrian-Herrada, K. Konate, Q.N. Nguyen, G.K. McMaster, R. Brasseur, F. Heitz, G. Divita, A new potent secondary amphipathic cell-penetrating peptide for siRNA delivery into mammalian cells, Mol. Ther. 17 (2009) 95-103.

[39] B. Jacob, Y. Kim, J.K. Hyun, I.S. Park, J.K. Bang, S.Y. Shin, Bacterial killing mechanism of sheep myeloid antimicrobial peptide-18 (SMAP-18) and its Trp-substituted 
analog with improved cell selectivity and reduced mammalian cell toxicity, Amino Acids 46 (2014) 187-198.

[40] R.E.W. Hancock, D.S. Chapple, Peptide antibiotics, Antimicrob. Agents Chemother. 43 (1999) 1317-1323.

[41] D.A. Phoenix, S.R. Dennison, F. Harris, Antimicrobial Peptides, First edition, Wiley-VCH Verlag GmbH \& Co, Weinheim, Germany, 2013.

[42] M.-D. Seo, H.-S. Won, J.-H. Kim, T. Mishig-Ochir, B.-J. Lee, Antimicrobial peptides for therapeutic applications; a review, Molecules 17 (2012) 12276-12286.

[43] D.L. Paterson, Impact of antibiotic resistance in gram-negative bacilli on empirical and definitive antibiotic therapy, Clin. Infect. Dis. 47 (2008) S14-20.

[44] D.J. Craik, D.P. Fairlie, S. Liras, D. Price, The future of peptide-based drugs, Chem. Biol. Drug Des. 81 (2013) 136-147.

[45] G.F. King, Venoms as a platform for human drugs: translating toxins into therapeutics, Expert Opin. Biol. Ther. 11 (2011) 1469-1484.

[46] S.T. Henriques, M.N. Mel, M.A.R.B. Castanho, Cell-penetrating peptides and antimicrobial peptides: how different are they?, Biochem. J. 399 (2006) 1-7.

[47] J. Howl, S. Matou-Nasri, D.C. West, M. Farqhar, J. Slaninová, C.-G. Östenson, M. Zorko, P. Östlund, S. Kumar, Ü Langel, J. McKeating, S. Jones, Bioportide: an emergent concept of bioactive cell penetrating peptide, Cell. Mol. Life Sci. 69 (2012) 2951-2966.

[48] J. Howl, S. Jones, Insights into the molecular mechanisms of action of bioportides: a strategy to target protein-protein interactions, Exp. Rev. Mol. Med. 17 (2015) e1.

[49] H. Mukai, M. Kikuchi, Y. Suzuki, E. Munekata, A mastoparan analog without lytic effects and its stimulatory mechanisms in mast cells, Biochem. Biophys. Res. Commun. 362 (2007) 51-55.

[50] S. Nakao, K. Komagoe, T. Inoue, T. Katsu, Comparative study of the membrane-permeabilizing activities of mastoparans and related histamine-releasing agents in bacteria erythrocytes, and mast cells, Biochim. Biophys. Acta 18018 (2011) 490-497.

[51] W. Chen, X. Yang, X. Yangm, L. Zhai, Z. Lu, H. Yu, Antimicrobial peptides from the venoms of Vespa bicolor Farbricius, Peptides 29 (2008) 1887-1892.

[52] B.M. de Souza, A.V. da Silva, V.M. Resende, H.A. Arcuri, M.P. Dos Santos Cabrera, J. Ruggiero Neto, M.S. Palma, Characterization of two novel polyfunctional mastoparan peptides from the venom of the social wasp Polybia paulista, Peptides 30 (2009) 1387-1395.

[53] M.J. Yang, W.-Y. Lin, C.-H. Lin, C.-L. Shyu, R.F. Hou, W.-C. Tu, Enhancing antimicrobial activity of mastoparan-B by amino acid substitution, J. Asia Pac. Entomol. 16 (2013) 349-355.

[54] H. Sato, J.B. Feix, Peptide-membrane interactions and mechanisms of membrane destruction by amphipathic $\alpha$-helical antimicrobial peptides, Biochim. Biophys. Acta 1758 (2006) 1245-1256.

[55] Y. Shai, Mechanism of the binding, insertion and destabilization of phospholipid membranes by $\alpha$-helical antimicrobial and non-selective membrane-lytic peptides, Biochim. Biophys. Acta 1462 (1999) 55-70.

[56] Y. Shai, Z. Oren, From carpet mechanism to de-novo designed diasteromeric cell-selective antimicrobial peptides, Peptides 22 (2001) 1629-1641.

[57] J.R. Henriksen, T. Etzerodt, T. Gjetting, T.L. Andresen, Side chain hydrophobicity modulates therapeutic activity and membrane selectivity of antimicrobial peptide mastoparan-X, PLoS One 9 (2014) e91007.

[58] G. Kroemer, L. Galluzzi, C. Brenner, Mitochondrial membrane permeabilization in cell death, Physiol. Rev. 87 (2007) 99-163.
[59] S.E. Horvath, G. Daum, Lipids of mitochondria, Prog. Lipid Res. 52 (2013) 590-614.

[60] T.J. Silhavy, D. Kahner, S. Walker, The bacterial cell envelope, Cold Spring Harb. Perspect. Biol. 2 (2010) a000414.

[61] T.J. Beveridge, Structures of Gram-negative cell walls and their derived membrane vesicles, J. Bacteriol. 181 (1999) 4725-4733.

[62] C.J. Henwood, T. Gatward, M. Warner, D. James, M.W. Stockdale, R.P. Spence, K.J. Towner, D.M. Livermore, N. Woodford, Antibiotic resistance among clinical isolates of Acinetobacter in the UK, and in vitro evaluation of tigecycline (GAR-936), J. Antimicrob. Chemother. 49 (2002) 479-487.

[63] S.M. Bowman, S.J. Free, The structure and synthesis of the fungal cell wall, BioEssays 28 (2006) 799-808.

[64] L.P. Erwig, N.A.R. Gow, Interactions of fungal pathogens with phagocytes, Nat. Rev. Microbiol. 14 (2016) 163-176.

[65] M.A. Ghannoumi, L.B. Rice, Antifungal agents: mode of action mechanisms of resistance, and correlation of these mechanisms with bacterial resistance, Clin. Microbiol. Rev. 12 (1999) 501-517.

[66] D.J. Sloan, V. Parris, Cryptococcal meningitis: epidemiology and therapeutic options, Clin. Epidemiol. 6 (2014) 169-182.

[67] S. Avram, D. Duda-Seiman, F. Borcan, B. Radu, C. Duda-Seiman, D. Mihailescu, Evaluation of antimicrobial activity of new mastoparan derivatives using QSAR and computational mutagenesis, Int. J. Pept. Res. Ther. 17 (2011) 7-17.

[68] M.A. Toropova, A.M. Veselinovic, J.B. Veselinovic, D.B. Stojanović, A.A. Toropov, QSAR modelling of the antimicrobial activity of peptides as a mathematical function of a sequence of amino acids, Comput. Biol. Chem. 59 (2015) 126-130.

[69] M. Moreno, E. Zurita, E. Giralt, Delivering wasp venom for cancer therapy, J. Control. Release 182 (2014) 13-21.

[70] L. Liu, K. Xu, H. Wang, P.K.J. Tan, W. Fan, S.S. Venkatraman, L. Li, Y.-Y. Yang, Self-assembled cationic peptide nanoparticles as an efficient antimicrobial agent, Nat. Nanotechnol. 4 (2009) 457-463.

[71] C.-H. Lin, R.F. Hou, C.-L. Shyu, W.-Y. Shia, C.-F. Lin, W.-C. Tu, In vitro activity of mastoparan-AF alone and in combination with clinically used antibiotics against multiple-antibiotic-resistant Escherichia coli isolates from animals, Peptides 36 (2012) 114-120.

[72] M.P. dos Santos Cabrera, B.M. de Souza, R. Fontana, K. Konno, M.S. Palma, W.F. de Azevedo Jr., J. Riggiero Neto, Conformation and lytic activity of eumenine mastoparan: a new antimicrobial peptide from wasp venom, J. Pept. Res. 64 (2004) 95-103.

[73] X. Xu, J. Li, Q. Lu, H. Yang, R. Lai, Two families of antimicrobial peptides from wasp (Vespa magnifica) venom, Toxicon 47 (2006) 249-253.

[74] H. Zare-Zardini, A. Taheri-Kafrani, M. Ordooei, L. Ebrahimi, B. Tolueinia, M. Soleimanizadeh, Identification and biochemical characterization of a new antibacterial and antifungal peptide derived from the insect Sphodromantis viridis, Biochemistry (Moscow Russ. Fed.) 80 (2015) 433-440.

[75] V. Čeřovský, J. Slaninová, V. Fučík, H. Hulacová, L. Borovicková, R. Jezek, L. Bednárová, New potent antimicrobial peptides from the venom of Polistinae wasps and their analogs, Peptides 29 (2008) 992-1003.

[76] U. Soomets, M. Lindgren, X. Gallet, M. Hällbrink, A. Elmquist, L. Balaspiri, M. Zorko, M. Pooga, R. Brasseur, Ü. Langel, Deletion analogues of transportan, Biochim. Biophys. Acta 1467 (2000) 165-176. 